\title{
Neoliberalism and our Precarious Culture
}

\section{lan Raymond B. Pacquing}

\begin{abstract}
The fluidity, contradictions, and multiplicity of the neoliberal structures fragment the historical continuity of our culture. The signifying chain, which our culture serves, is shattered and hence there is a constant need to regain our lost identity. However, the massive concentration of the market economy dissuades us from achieving this end. Psychoanalytically, we regress into the pregenital stages of human development, which give rise to narcissistic traits. Social narcissism finds its expressions through the accumulation and possessions of lacuna of "images" and "appearances" that serve to cover existential issues in contemporary life. Reliance on surface reality, this modernday psychopathology deadens our individual convictions on social and political issues, as well as our fidelity in emotional matters. As a consequence, we lose concern over things that might be equally or more important for the survival of our society-tradition.
\end{abstract}

Keywords: neoliberalism, culture, narcissism, transference

\section{The Neoliberal Paradigm}

fter World War II, Friedrich Hayek called for a meeting in what was
called The Mount Pelerin Society in which our so-called freedom and
liberty should be grounded on the market economy. ${ }^{1}$ Liberty and
freedom, which lead towards the self-determining individual, must now
follow a peculiar kind of rationality, which we may refer to as the capitalist

${ }^{1}$ The real reason why both Mises and Hayek argued for freedom in the market was to protect capitalist agenda of the U.S. which was threatened by the presence of socialism and communism. The fundamental rights of the individual must prevail over any regulation from external authorities including the State. Hence, historians, economists, philosophers, and political scientists have met in what is called Mont Pelerin Society to discuss what could possibly protect the freedom of the individual and the State from a totalitarian form of government. See Dieter Plehwe and Tom Mills "Defending Capitalism: The Rise of the Neoliberal Thought Collective (Part 1)," in New Left Project (12 March 2012), $<$ http://www.newleftproject.org/index.php/site/article comments/defending capitalism the ris e_of_the_neoliberal_thought_collective_part_1>.

(c) 2017 lan Raymond B. Pacquing

http://www.kritike.org/journal/issue 20/pacquing june2017.pdf

ISSN 1908-7330

(cc) $\mathrm{BY}-\mathrm{NC}-\mathrm{ND}$ 


\section{NEOLIBERALISM AND OUR PRECARIOUS CULTURE}

rationality. ${ }^{2}$ Such economic rationality believes that the free market of various capitalist competitors maximizes consumers' satisfaction. ${ }^{3}$ In fact, Friedman, Hayek and Von Mises took these human faculties of liberty and freedom as the cornerstone of their political and economic treatises from which neoliberal thinking takes its course. ${ }^{4}$ Both argued that neoliberalism pushes human potentiality, creativity, and productivity to grow and nourish along the market economy. ${ }^{5}$ Such philosophy is centered on one axiom, i.e., freedom of the market means freedom for everybody to achieve the dream of fulfilling one's own autonomy. ${ }^{6}$ In this context then, the free market assumes that the economic sphere is a conditio sine qua non for the fulfillment of human life. Leys even asserts that the purpose of this economic restructuring is something material, i.e., "radical transformation in both the structure and the management of the world economy ... creating for the first time in history a truly unified global capitalist economy ... reflecting the interests of transnational capital." 7

Taking the individual as the cornerstone of the neoliberal economic agenda, neoliberal apologists argue that there is no alternative to deregulation, free trade, and individual entrepreneurship, and competitions. As such, there is no such thing as society, and everything must be reduced to

2 The difference between the classical laissez fair liberalism and neoliberalism is that the former wanted "to roll back the state, to let private enterprise make profits relatively unhindered by legislation (e.g., safety at work, trade union rights, minimum wage, etc.), and unhindered by the tax costs of a welfare state. On the hand, neoliberalism needs a strong state to impose the policies enunciated by the market capital. See Ravi Kumar and Dave Hill, "Introduction: Neoliberal Capitalism and Education," in Global Neoliberalism and Education and its Consequences, ed. by Ravi Kumar and Dave Hill (New York: Routledge, 2009), 3.

${ }^{3}$ See Richard Peet, Unholy Trinity (Philippines: IBON Books, 2004), 3. Further, the work of Kristol argues that in a capitalist economy, all individuals are endowed with the same political rights. However, as far as economic rights are concerned, the individual depends upon economic factors that ultimately determine winners and losers in the market competition. This is the reason why some professional courses, according to Kristol, are paid better than the others. Economically, the standard for success depends upon what capitalist society projects and not what the individual wants. See Irving Kristol, "A Capitalist Conception of Justice," in Business Ethics, $3^{\text {rd }}$ ed., ed. by W. Michael Hoffman and Robert E. Frederick (New York: McGraw Hills, Inc., 1995), 68.

${ }^{4}$ Cf. F.A. Hayek, The Constitution of Liberty (Chicago: University of Chicago Press, 1978), 3. On the other hand, von Mises argues that freedom means to entail one's autonomy and individuality into the market enterprise. See Ludwig von Mises, Preface to Liberalism, trans. by Ralph Raico (California: Cobden Press, 1985), xvi.

${ }^{5}$ In fact, Fukuyama says that the liberal market economy which is the basis of capitalist enterprise becomes the final arrangement of modernity. See Francis Fukuyama, The End of History and the Last Man (New York: The Free Press, 1992), ix.

${ }^{6}$ Cf. Peet, Unholy Trinity, 3.

7 Collin Leys, "The Rise and Fall of Development Theory," in The Anthropology of Development and Globalization, ed. by Marc Edelman and Angelique Haugerud (U.S.A.: Blackwell Publishing, 2005), 114.

(C) 2017 lan Raymond B. Pacquing

http://www.kritike.org/journal/issue 20/pacquing june2017.pdf

ISSN 1908-7330

(cc) BY-NC-ND 
and for the individual, private property, personal responsibility and family. Further, this philosophy ignores morality, religion, arts, and culture, which provide values and elevate humanity above the animal condition. ${ }^{8}$ Within this context, neoliberalism wants to achieve a society in which every individual, with a minimum dependence on discretionary authority of his rulers, would enjoy the privileges and responsibility of determining his own conduct within previously defined frameworks of rights and duties. ${ }^{9}$ However, I argue that unlike the vision of the Enlightenment, ${ }^{10}$ neoliberalism has produced and continuously fabricates social reality because of a particular social psychic matrix which Fromm calls the social character. This brings me to the second part of this essay.

\section{Erich Fromm's Notion of Social Character}

The massive concentration of the capital has brought changes in the way we see reality. For how an individual relates to the world is coursed through that psychic matrix called the social character. ${ }^{11}$ It is an energy which is released by the individual for survival, channeled into various paths that enable the individual to react adequately to the task demanded by the market economy. ${ }^{12}$ Further, it must be noted that the socio-economic forces, according to Fromm, serve as the fulcrum in the unconscious institutionalization of character. ${ }^{13}$ As Wiggerhaus observes "What connections there are between the social development of humanity, particularly its economic and technical development, and the development of

\footnotetext{
${ }^{8}$ See Simon Clarke, "The Neoliberal Theory of Society," in Neoliberalism: A Critical Reader, ed. by Alfredo-Saad Filho and Deborah Johnston (London: Pluto Press, 2005), 51.

${ }^{9}$ Cf. Hayek, Constitution of Liberty, 3. See also Michael Perelman, The Invention of Capitalism, (London: Duke University Press, 2000), 15.

${ }^{10}$ Fromm argues that The Enlightenment period was believed to be the answer to man's bewilderment. He says, "pride in reason as man's instrument for his understanding and mastery of nature; optimism in the fulfillment of the fondest hopes of mankind ... by virtue of his reason he has built a material world the reality of which surpasses even the dreams and visions of fairy tales and utopias ..." See Erich Fromm, Man for Himself (New York: Holt and Company, 1947), 4.

${ }^{11}$ Cf. Rainer Funk, Erich Fromm: The Courage to be Human (New York: Continuum, 1982), 19

${ }^{12}$ Cf. Lawrence Wilde, Erich Fromm and the Quest for Solidarity (New York: Palgrave McMillan, 2005), 8.

${ }^{13}$ Fromm argues that individual psychology is also a social one. He says, "... the personality structure of the individual is determined by social factors and on the other hand, with the extent to which psychological factors themselves influence and alter the social process. The two sides of the problem are indissolubly bound together. The personality structure, which we can recognize as affecting the social process, is itself the product of this process ..." Cf. Erich Fromm, "Man's Impulse Structure and Its Relation to Culture" in Beyond Freud: From Individual to Social Psychology, ed. by Rainer Funk (New York: American Mental Health Foundation, 2010), 17.
} 


\section{NEOLIBERALISM AND OUR PRECARIOUS CULTURE}

its mental faculty, particularly the ego-organization of the human being?" 14 The oscillation between the economic forces and the mental development of society brings forth the formation of the social character. Following Fromm, Ozzane says:

In studying the psychological reactions of a social group, we deal with the character structure of the group, that is, of individual persons; we are interested, however, not in the peculiarities by which these persons differ from each other, but in that part of their character structure which is common to most members of the group. We call this character the social character. 15

Naturally, the function of society is determined by its economic and political goals, and it has the ways and means to direct its members to attain such goals. It also has the power to suppress the rights of its members or it can further develop them by means of instituting programs that would cater to the individual's full growth and development. To attain such goals, its members must be guided accordingly. Society then must project an inner compulsion for the realization of such goals, which are economic, political, social, and cultural. Thus, reforms through legislations of laws, policies, or ordinances become inevitable. Through them, citizens acquire behavioral patterns that jibe with the demands of the social constructs. In other words, individual instinctual drives must adjust and adhere to these social structures in order for society to run smoothly. Any individual has to partly repress or postpone, though unconsciously, his sexual desires for the advancement of society. At this point, the interplay between the satisfactions of these drives within the social-economic structures led Fromm to assert that there is a connection between the material forces of society and the psychic apparatus of men. The dialectic relation of these two results in what Fromm calls social character. He then says:

In speaking of the socio-economic structure of society as molding one's character, we speak only of one pole in the interconnection between social organization and man. The other pole to be considered is man's nature .... The social process can be understood only if we start out

\footnotetext{
${ }^{14}$ Rolf Wiggerhaus, The Frankfurt School: Its History, Theories, and Political Significance, trans. by Michael Robertson (Cambridge: MIT Press, 1995), 5.

${ }^{15}$ Henry Ozzane, "Social Character as Sociological Concept" in American Sociological Review, 8:5 (1943): 519-524.

(C) 2017 Ian Raymond B. Pacquing

http://www.kritike.org/journal/issue 20/pacquing june2017.pdf

ISSN 1908-7330
}

(c) ) BY-NC-ND 
with the knowledge of the reality of man, his psychic properties as well as his physiological ones .... ${ }^{16}$

Further, Wilde opines that "The social character develops as an adaptation to changes in socio-economic structure, and in turn, it influences the formation of ideas, doctrines, and even individual concepts. Reciprocally, the ideological superstructure then reinforces particular social characters that are functional for the further development of the socioeconomic structure. The social character operates as an internalization of external necessities and Fromm sees it as the harnessing of human energy for the tasks of a given economic and social system."17

Hence, why particular members of society are motivated to want to act as they have to act and finding gratification in acting is the very function of the social character. ${ }^{18}$ Social character is the psychic force built between the material base of society and its superstructure. It is through this psychic force that "thinking is not an exclusively intellectual process, and that it is bound up with the entire character structure. Doctrines, ideals, or even individual concepts have an "emotional matrix" rooted in the character structure of the individual, and the fact that ideas have an emotional matrix is regarded as the key to understanding the spirit of a culture. ${ }^{19}$

Taken in these contexts then, we ask how neoliberal structures affect the Filipino culture. What is the influence of the institutionalization of an economic rationality on the Filipino ways of expressing their social identity? Does this economic rationality lead towards fulfillment and development of common identity, which is manifested in one's culture? This leads me to the third part of this paper.

${ }^{16}$ Erich Fromm, Beyond the Chains of Illusion (New York: Continuum, 1962), 62-64.

17 Wilde, Erich Fromm and the Quest for Solidarity, 20.

18 See Erich Fromm, The Sane Society (Canada: Holt, Rinehart, and Winston, 1955), 79. Social characterology can only be understood in reference to the function it may serve to the members of society. See also Erich Fromm, "Psychoanalytic Characterology and Its Relevance for Social Psychology," in The Crisis of Psychoanalysis (New York: Henry Holt and Company, 1970), 3. More than the initial parental authority being exerted unto the child, there are social forces or civil institutions which stumped their affects unto him. This is called by Gramsci as the civil institutions which assert their power over the human individual. It is the "powerful system of fortresses and earthworks ... which provide the basis for an intellectual and moral reform." Peter Mayo, "In and Against the State': Gramsci, War of Position, and Adult Education," in Journal for Critical Education Policy Studies, 3:2 (2005): 3. Golding also explains “Outside of society, then, the individual has no history, no identity, no meaning, and no humanity. From the moment of birth, a child finds itself in a social world which, through those responsible for the infant's care, begins to shape that being into a person." Robert Golding, "Freud, Psychoanalysis, and Sociology: Some Observations on the Sociological Analysis of the Individual," in The British Journal of Sociology, 33:4 (1982): 546-547

${ }^{19}$ See Wilde, Erich Fromm and the Quest for Solidarity, 20.

(c) 2017 lan Raymond B. Pacquing

http://www.kritike.org/journal/issue 20/pacquing june2017.pdf

ISSN 1908-7330 


\section{NEOLIBERALISM AND OUR PRECARIOUS CULTURE}

\section{Neoliberalism and our Filipino Culture}

The Philippines has fully embraced neoliberal policies as early as the ${ }^{\prime} 90 \mathrm{s.}^{20}$ Since there is now a disowned responsibility of the sovereign state, neoliberalism pushes the individual and communities to govern themselves in a manner dictated upon them. ${ }^{21}$ One needs to become an "economic atom who dances to the tune of economic management." 22 In this sense, what is now carved in the conscious mind is a kind of rationality that caters to the demands of a capitalist structure. ${ }^{23}$ Human reason has just become another tool in the apparatus of production, and thinking has been reduced to the level of the economic mainstream. ${ }^{24}$ As a result, "the agential exercise of our choice over what to consume, our control over what we desire, our consent to the forces that enable our choices and ignite our desires and the unbridled circulation of capital and knowledge that is meant for our accumulation are primary markers of middle-class modernity." ${ }^{25}$ Honneth describes this as the "commercialization" of everyday life so that human and individual

${ }^{20}$ Since there were no credible domestic alternatives to reinforce the Philippine economy during Corazon Aquino's regime, and since the world was witnessing the collapse of socialism in Eastern Europe, the fast-growing economy of Asia pacific region, and the success of Thatcher-Reagan neoliberal method, Philippine technocrats envied what was happening to the other rising Asian tigers. When the Ramos-Macapagal regimes through Roberto de Ocampo as Secretary of Finance and NEDA chief Cielito Habito made the country to be a party to the ASEAN Free Trade Area, and eventually joined the World Trade Organization in 1995, domestic casualties occurred. Bello says, "The list of industrial casualties included paper products, textiles, ceramics, rubber products, furniture and fixtures, petrochemicals, beverage, wood, shoes, petroleum oils, clothing accessories, and leather goods. By the early years of this decade, the country's textile industry had shrunk from 200 to less than 10 firms." In 2003, the irreversible effect led Finance Secretary Isidro Camacho to admit that there is indeed an imbalance implementation of trade liberalization and it is to our disadvantage. See Walden Bello, "Neoliberalism as Hegemonic Ideology in the Philippines: Rise, Apogee, and Crisis" (Plenary Paper presented at the National Conference of the Philippine Sociological Society, Philippine Social Science Center (PSSC) Building, Quezon City, Metro Manila, 16 October 2009. See also Walden Bello, "Neoliberalism as Hegemonic Ideology in the Philippines: Rise, Apogee, and Crisis," in Focus on the Global South, <http://focusweb.org/node/1534>, 3.

${ }^{21}$ Cf. Toby Miller, Cultural Citizenship (Philadelphia: Temple University Press, 2007), 2.

22 C. Lakshmanna, Democratic Planning: Problems and Process (Calcutta: Minerva Associates Publications, 1975), 101.

${ }^{23}$ Fromm was criticizing the capitalist structure of the early 20th century. However, his ideas are now more pressing as this structure become globalized and its policies penetrate every aspect of human life. Cf. Fromm, The Sane Society, 55. See also David Harvey, Brief History of Neoliberalism (New York: Oxford University Press, 2005), 39-40.

${ }^{24} \mathrm{Cf}$. Aaron Caleb Sams, "Horkheimer and the Critique of Instrumental Reason," in Academia (2014), $<$ https://www.academia.edu/4104495/Horkheimer_and_the_Critique_of_Instrumental_Reason $>$

${ }^{25}$ Oishik Sirkar and Dipika Jain, "Neoliberal Modernity and the Ambiguity of its Discontents: Post/Anti-colonial Disruptions of Queer Imperialism," in Jindal Global Law Review, 4:2 (2013): 3-5. Italics are mine.

(c) 2017 Ian Raymond B. Pacquing

http://www.kritike.org/journal/issue 20/pacquing june2017.pdf

ISSN 1908-7330

(c) $\mathrm{BY}-\mathrm{NC}-\mathrm{ND}$ 
relationships "interact with a lifeless object without a trace of inner sentiment or any attempt at understanding the other's point of view." 26 As we adapt ourselves to the demands of neoliberal ideology, ${ }^{27}$ we acquire character traits that resemble the socio-economic structure. We possess the character of entrepreneurship, commercial competencies, and individual competition which now become our social behavior in the social sphere. Thus, neoliberalism as philosophy, Giroux suggests, is a "market ideology driven not just by the accumulation of capital, but also by an ability to reproduce itself as a form of biopolitics reaching into and commodifying all aspects of social and cultural life." ${ }^{28}$ Human consciousness is altered and commoditized at the service of this economic paradigm. ${ }^{29}$ Our individual and social identity is now set aside. ${ }^{30}$

Neoliberal structures do not exempt our traditional values which serve as the locus of our emotional experience as belonging to an ethnic community. ${ }^{31}$ Our beliefs and traditions are dissuaded from a praxis which we could ultimately call "ours." 32 Giroux contends that the relentless attack of

${ }^{26}$ Axel Honneth, Reification: A New Look at an Old Idea, ed. by Martin Jay (New York: Oxford University Press, 2008), 18.

${ }^{27}$ Giddens argues that in interpreting Marx, an individual needs to "adapt" instead of having an "active mastery" over nature since the forces of capitalism reduce human productive activity into an alienated form. See Anthony Giddens, Capitalism and Modern Social Theory (New York: Cambridge University Press, 1991), 13

${ }^{28}$ Henry A Giroux, "Neoliberalism, Youth, and the Leasing of Higher Education," in Global Neoliberalism and Education and its Consequences (New York: Routledge, 2009), 30.

${ }^{29}$ Cf. Noam Chomsky, Profit Over the People: Neoliberalism and the Global Order (New York: Seven Stories Press, 1999), 53.

${ }^{30}$ In his book, Man for Himself, Fromm says that "one individual represents the human race. He is a specific example of the human species. He is 'he' and he is 'all' ... he is the representative of all characteristics of the human race. Further he argues 'he (man) is the archaic man, the beast of prey, the cannibal, the idolater, but he is also the being with the capacity for reason, for love, and for justice ... sinner and saint, child and adult, sane and insane, man as he was in the past and man as he will be in the future." See Fromm, Man for Himself, 38; Cf. Erich Fromm, On Being Human, ed. by Rainer Funk (New York: Continuum, 1999), 10-11.

31 "Ethnic identity includes both emotional and cognitive phenomena. Besides the unconscious strivings and emotions it embraces self-consciousness of a man as a representative of this community, his conscious estimation of the ethnic group he belongs to in contrast to other groups." Further, "If man is deprived of his usual base of socialization he perceives his state as loss of identity ... and this becomes unbearable." Tatiana Panfilova, "Identity as a Problem of Today," in Fromm Forum, 14 (2010): 2. Thus modern capital pushes the self to slip away leaving only an empty space. Cf. Stephen Frosh, Identity Crisis: Modernity, Psychoanalysis, and the Self, (New York: Palgrave McMillan, 1991), 6-7.

${ }^{32}$ De Torre explains that culture is in fact a characteristic of becoming human. He says, "Culture is that through which man, as man, becomes more man, 'is' more, has more access to 'being' .... man, through his 'having' can at the same time 'be' more fully a man, become more fully a man in all the dimensions of his existence, in everything that characterizes his humanity." Joseph M. De Torre, Work, Culture, Liberation (Manila: Vera-Reyes, 1985), 17-18. Further, it must be noted that values, i.e., Filipino values are seen as criteria for recognizing and evaluating social

(c) 2017 lan Raymond B. Pacquing

http://www.kritike.org/journal/issue 20/pacquing june2017.pdf

ISSN 1908-7330 


\section{NEOLIBERALISM AND OUR PRECARIOUS CULTURE}

neoliberalism on our values resulted in the commodification of life so that "social relations between parents and children, doctors and patients, teachers and students are reduced to that of supplier and customer just as the laws of market replace the non-commodified values capable of defending vital public goods and spheres." 33 Further, with the multiplicity, fluidity, and contradictions brought about by modern market economy, ${ }^{34}$ our efforts to establish links with others within our social and traditional interpersonal structures disappear. ${ }^{35}$ As a result, everything, including the self, becomes spilling and thrilling in the process of the capital. ${ }^{36}$ Our traditional values absorb the character imprint of the capital where our ontological center is amassed into one common desire, which is money. ${ }^{37}$ With the dictates of the private capital, we unconsciously live our lives in accordance with measurability, quantifiability, and instrumentations. ${ }^{38}$ Neoliberalism creates in us the character of trampling, crushing, elbowing, and treading on each other's heels. ${ }^{39}$ It is no longer a reasoned argument arising from public discourses; it is no longer freedom to enjoy one's own liberty; it is no longer the creative and productive potentials, which emanate from the individual himself. Rather, it is a homogenous economic discourse where human faculties are subsumed and dominated through the private capital. What we have is a corporatist culture and we assume a characterology in consonance thereof. ${ }^{40}$ This corporatism hijacks the unique character of our traditional cherished values so that our individual and social relationships as belonging to a group, community, or ethnicity lead to social coma and political

realities in terms of their desirability, significance, importance, worth, or merit. Cf. F. Landa Jocano, Filipino Value System (Quezon City: Punlad Research House, 1997), 19.

${ }^{33}$ Henry A. Giroux, "Neoliberalism, Youth, and the Leasing of Higher Education”, 30-

31.

${ }^{34}$ I use neoliberalism and market economy synonymously in this essay.

${ }^{35}$ Cf. Stephen Frosh, Identity Crisis: Modernity, Psychoanalysis, and the Self, 6-7.

${ }^{36}$ Cf. Ibid.

${ }^{37}$ Cf. Michael Hardt and Antonio Negri, Empire (London: Harvard University Press, 2000), 318-326

${ }^{38}$ Cf. Deborah Cook, Adorno, Habermas, and the Search for a Rational Society (New York: Routledge, 2004), 10-11. The hybridization of capital has led to the movements from social to the political and the juridical which have defined constituent processes. The movement of the capital takes the form of control that enunciates the relationship between the state and its constituents. Neoliberal policies reify life so that our thoughts, actions, and feelings are swayed into one paradigm. It attracts our psychic energies to imbibe an economy which is thought of as liberating and thus humanizing. These policies build a character where we are cajoled into believing that we become all the more free. Cf. Jodi Dean, Democracy and Other Neoliberal Fantasies (U.S.A.: Duke University Press, 2009), 55. See also George Lukacs, "History and Class Consciousness 1920" in History and Class Consciousness, ed. by Andy Blunden, trans. by Rodney Livingstone (Meril Press, 1967), 12.

${ }^{39}$ Cf. Erich Fromm, The Revolution of Hope (New York: Rinehart and Holt, 1970), 39.

${ }^{40}$ Cf. Henry Giroux, Zombie Politics and Culture in the Age of Casino Capitalism (New York: Peter Lang Publishing Co., 2011), 22.

(C) 2017 lan Raymond B. Pacquing

http://www.kritike.org/journal/issue 20/pacquing_june2017.pdf

ISSN 1908-7330

(cc) BY-NC-ND 
amnesia. ${ }^{41}$ All of these happen because of our unconscious libidinal motivation which serves as the characterological trait of neoliberal structures. ${ }^{42}$ Consequently, our culture, which provides for the development of the self, is now dissolved. ${ }^{43}$ The signifying chain of our traditions and beliefs which we muster in order to allow a meaningful representation of reality has been dissipated. ${ }^{44}$ Panfilova explains that "under globalization, cultures are unified, national and cultural differences are eliminated and borders between cultural and ethnic groups are obliterated. Under these circumstances man is deprived of his usual base of socialization and lack of identity appears." 45 What neoliberal values project are just the surface materiality of images and appearances that would appear and reappear as a matter of the massive concentration of the capital. ${ }^{46}$ San Juan says that "all happens for the benefit of consumerist pleasures, solipsist jouissance, and other hedonistic games that foster the status quo of domination and subordinations." 47

Taking these into context, I argue then that there is a disparity on how we practice our values privately and within our own community, and the way we behave in public, which is in accordance to the demands of neoliberal bureaucratic forces. ${ }^{48}$ We live and engage our public lives under a western capitalist imprint camouflaged under the banner of Filipino culture. ${ }^{49}$ For instance, in our own community, we practice our values in accordance to the real Filipino spirit. We uphold and cherish them most when interacting with our fellow Filipinos. Further, we practice them in the context of commonly shared meanings of things, events, or actions that would bring the best in us

${ }^{41}$ Cf. Ibid.

${ }^{42}$ Cf. Slavoj Žižek, Living in the End Times (London: Verso, 2010), 20. Further, this reconceptualization of ideology captures the orthodox neoliberal understanding of market society as a spontaneous natural order that is already immanent in the structures of the social world, rather than a social order to be constructed upon a pre-existing reality. See Japhy Wilson, "The Shock of the Real: The Neoliberal Neurosis in the Life and Times of Jeffrey Sachs" in Antipode, 46:1 (2014): 302.

${ }^{43}$ Cf. Frosh, Identity Crisis: Modernity, Psychoanalysis, and the Self, 56.

${ }^{44}$ Cf. Ibid.

${ }^{45}$ Panfilova, "Identity as a Problem Today," 43-51.

${ }^{46}$ Cf. Peet, Unholy Trinity, 2.

${ }^{47}$ E. San Juan, From Globalization to National Liberation: Essays of Three Decades (Manila: UP Press, 2008), xii.

48 Jocano argues that these two models simultaneously exist but they function separately. See F. Landa Jocano, Issues and Challenges in Filipino Value Formation (Quezon City: Punlad Research House, 1992) 4-5.

${ }^{49} \mathrm{~F}$. Landa Jocano says that our performance in social and economic developments compared with other Asian countries is not well. Our "damaged culture" which pulls back the Filipinos towards regression can be traced back in history. The Western model of transacting our socio-economic life clashes with our own traditional values. See F. Landa Jocano, Issues and Challenges in Filipino Value Formation, 4-5.

(c) 2017 lan Raymond B. Pacquing

http://www.kritike.org/journal/issue 20/pacquing june2017.pdf

ISSN 1908-7330 


\section{NEOLIBERALISM AND OUR PRECARIOUS CULTURE}

as Filipinos. ${ }^{50}$ These cherished values become the fundamental elements of how we share and express our own culture as a class or group bounded by a common identity. Without these cherished values, we are divested of our identity and of our need to collaborate with the very fabric of the universe in order to bestow meaning, purpose, and dignity upon our existence. ${ }^{51}$ Values which are rooted in one's culture speak of the very unconscious region which is ingrained as elements of individual and social identities. Collectively, we, Filipinos, become accustomed to these traditions where we can experience our fellows because we share one common possession which is our culture. ${ }^{52}$

Nevertheless, the social character emanating from the concentration of the capital deadens these cultural aspirations to the extent that we now need to dance to the tune of economic management. In this sense, our psychic energies become canalized under these neoliberal arrangements. ${ }^{53}$ The psychic matrix reproduced therein becomes our logic for legal and civic transactions; we unconsciously follow them as if this becomes the natural flow of social life. ${ }^{54}$ Thus, consciously, we imbibe the true spirit of our traditions, but unconsciously, we are swayed by the social character ingrained in us by the market economy. We are enmeshed in a network of neoliberal means and we lose the vision of the end which alone gives us significance. ${ }^{55}$ Hence, psychologically, our culture and the neoliberal character could not supplement each other, much less sustain each other. We now encounter "an inner incongruence in our sentiments and attitudes

\footnotetext{
${ }^{50}$ Cf. Jocano, Filipino Value System, 25.

${ }^{51}$ Cf. Ruth Nanda Anshen, "World Perspectives - What This Series Means," in Erich Fromm, To Have or To Be (London: Continuum, 2008), xvii.

52 In his book On Being Human, Fromm says that this humanistic experience consists in the feeling that nothing human is alien to one, that "I am you," that one can understand another human being because both of us share as our common possession the same elements of human existence ... the broadening of self-awareness that humanistic experience brings about-including as it does the transcending of consciousness and the revelation of the sphere of the social unconscious-enables man to experience himself in the full dimension of his shared humanity. Cf. Fromm, On Being Human, 11.

${ }^{53}$ Political life is subsumed under the power of the collective dimension of the market economy so that "command must be exercised to an ever greater extent over the temporal dimension of society and hence over the dimension of subjectivity." This happens because there is no firm place to stand on in order to make sense of the world. Thus, the only real for now is the philosophy of the globalizing order of the capital where the values are aggregated into one common plane which is money. Cf. Hardt and Negri, 318-326.

${ }^{54}$ Pines argues that the "the dominant ideological forms of thought represent something like the "common sense" of a society; they are the given, customary conceptions through which social agents comprehend their social experiences, and the normative ideals which social agents utilize for articulating their moral and political claims on one another." Christopher Pines, Ideology and False Consciousness (New York: State University of New York Press, 1993), 65.

${ }^{55}$ Erich Fromm, "Freedom in the Work Situation," in Arbeit - Entfremdung - Charakter, vol. 3 of The Yearbook of the International Erich Fromm Society (Münster: LIT Verlag, 1994), 3.
}

(c) 2017 lan Raymond B. Pacquing

http://www.kritike.org/journal/issue 20/pacquing june2017.pdf

ISSN 1908-7330

(c) $)$ BY-NC-ND 
caused by the clash of values in the models we use to conduct our behavior." 56 Either we follow those exogenous models or invoke our inner absolutes as our guide in our daily lives. ${ }^{57}$

The contradictions, fluidity, and multiplicity of the market economy shatter the historical continuity of our culture. Lasch argues that "we are fast losing the sense of belonging to a succession of generations originating in the past and stretching into the future. It is the waning of the sense of historical time-in particular, the erosion of any strong concern for posterity." 58 The signifying chain that our culture rightly serves in linking our past, present, and future snaps and the terrifying concentration of neoliberal ideology disallows an integrated and meaningful reality to be built. ${ }^{59}$ In neoliberal structures, there is a crushing of socially interactive framework of mutual recognition and adaptation. ${ }^{60}$ Its power annihilates social spaces and brings about the saturation of images that would appear and reappear as an expression of a capitalist ideology. ${ }^{61}$ In other words, we are not structured in stable and integrated ways; instead, we are full of contradictions, fluidities, frustrations, and impulses. ${ }^{62}$ Hence, neoliberal character dissuades the very locus of interactions, "throwing previous assumptions and traditions to the wind, undermining accepted ideas and modes of relationship between people and people, and between people and things." 63 As a result, there arises a disassociation and an emotional withdrawal which result in the alienation of the self, which in turn is transformed into a wish not to be oneself. ${ }^{64}$

An alienated person, says Fromm, is estranged from himself, out of touch with himself. The individual does not experience himself as the center of his world. He rather creates an artificial world for himself. In the alienated individual, life is denied because of "unsatisfactory adaptation of instincts to social reality." 65 Control, creativity, independent thought is all baulked and

\footnotetext{
${ }^{56}$ Jocano, Issues and Challenges in Filipino Formation, 4-10.

${ }^{57}$ Cf. E. San Juan, Only by Struggle (Quezon City: Giraffe Books, 2002), 24.

58 Christopher Lasch, The Culture of Narcissism (New York: W.W. Norton and Company, 1979), 5 .

${ }^{59}$ See Frosh, Identity Crisis: Modernity, Psychoanalysis, and the Self, 56.

${ }^{60}$ Cf. Robert Dunn, Identity Crises: Social Critique of Postmodernity (London, University of Minnesota Press, 1998), 55-57.

${ }^{61}$ See Peet, Unholy Trinity, 2.

${ }^{62}$ See Frosh, Identity Crisis: Modernity, Psychoanalysis, and the Self, 3.

63 Ibid., 6.

${ }^{64}$ See Frederick Weiss, "Self-Alienation, Psychoanalysis and the Wholeness of Man," in Fortschritte der Psychoanalyse. Internationales Jahrbuch zur Weiterentwicklung der Psychoanalyse, ed. by A. Heigl-Evers, vol. 1 (Göttingen: Verlag für Psychologie - Dr. C. J. Hofgrefe, 1964), 6. We may also add that in an alienated self, powerlessness and isolation engulf the individual towards psychoanalytic regression and thus he needs somebody to make him secure. Cf. Erich Fromm, Greatness and Limitation of Freud's Thought (New York: Harper and Row, 1979), 42.

65 See Fromm, "Psychoanalytic Characterology and Its Relevance for Social Psychology,"165.
}

(c) 2017 lan Raymond B. Pacquing

http://www.kritike.org/journal/issue 20/pacquing june2017.pdf

ISSN 1908-7330 


\section{NEOLIBERALISM AND OUR PRECARIOUS CULTURE}

the inevitable result is a fight or flight on the part of the worker, apathy, destructiveness, and psychic regression. ${ }^{66}$ With an instrumentalized rationality coupled with a fragmented form of cultural life, there exists emptiness within. ${ }^{67}$ We seek worship figures that are considered savior and helpers even if, in reality, they may be half-mad. ${ }^{68}$ To the extent that the neoliberal structures restrict the libidinal satisfaction of an individual, madness pushes us towards corresponding intensification of pregenital impulses, which force the libido to flow backward to the pregenital zones. ${ }^{69}$ However, we could no longer go back in the pre-individual state; instead, we have to move forward in history. ${ }^{70}$ By doing so, we have to redirect our psychic energies to find stability as to our social and individual identity. ${ }^{71}$ Identity is the lasting refuge and honor amidst the precariousness of our culture. $^{72}$

However, I argue that since the social characterology of the market economy has turned our values and traditions into a world-less universe, the locus of the self is devoid of any human base, which is now unbearable. ${ }^{73}$ Our mental-emotional maturity and even our intellectual development are derailed because of the impact of the market economy. In other words, the instability of our culture results in a disembedded life.

Since everything solid melts into air and we are devoid of any ontological center to uphold our social identity, there is a need to make up

${ }^{66}$ Cf. Lakshmanna, Democratic Planning, 1. See also Fromm's The Sane Society, 124-130.

${ }^{67} \mathrm{Cf}$. Lasch, The Culture of Narcissism, 13.

${ }^{68}$ See Fromm, Greatness and Limitations of Freud's Thought, 42.

${ }^{69}$ For Fromm, the pregenital areas remain to be extraordinarily strong. The rejection or satisfaction experienced in early childhood makes the individual fixated either in the oral or anal stages of life. These fixations are intensified by the spirit projected by capitalism. See Ibid., 178-184. Human, 75 .

${ }^{70}$ See Erich Fromm, "A New Humanism as a Condition for the One World" in On Being

${ }^{71}$ See Fromm, Greatness and Limitation of Freud's Thought, 42. Psychoanalytically, culture is what Fromm describes as the all-nurturing mother who loves, caresses, protects her all her children equally. These human qualities can only be attained if man is rooted with his fellow man and rooted in nature. He says is it surprising to find in the average adult a deep longing for the security and rootedness which the relationship to his mother once gave him? Is it not to be expected that he cannot give up this intense longing unless he finds other ways of being rooted? To find his identity, man may be rooted in the family, clan, and later on in the society, nation, church which assume the same function which the mother had originally for the child ... The person who does not belong to the same clan is considered as alien and dangerous-as not sharing in the same human qualities which only the own clan possesses." See Fromm, The Sane Society, 37-40.

${ }^{72}$ Cf. Frosh, Identity Crisis: Modernity, Psychoanalysis, and the Self, 3.

${ }^{73}$ Cf. Panfilova, "Identity as a Problem of Today," 2.

(c) 2017 lan Raymond B. Pacquing

http://www.kritike.org/journal/issue 20/pacquing june2017.pdf

ISSN 1908-7330

(cc) BY-NC-ND 
for the self from the onslaught of the market economy. ${ }^{74}$ The self, says Lasch, contracts into a defensive core in order to search for an emotional equilibrium. ${ }^{75}$ Psychoanalytically, to search for this emotional state is a pressure to regress towards passive and primeval state where the world remains uncreated and unformed. Fromm maintains that with an individual without any form of security, it is but natural to regress and to sublimate libidinal desires by seeking worship figures considered as saviors or helpers. ${ }^{76}$ This means that the social characterology acquired from the prevailing conditions of modern capitalism brings about anxiety and tension, with which the only way to cope is to sublimate or regress and bring out narcissistic traits, which is a contemporary psychopathology. ${ }^{77}$ Narcissistic traits become a survival strategy in which the self is at the brink of breaking down because of the persecutory demands of the socio-economic environment. ${ }^{78}$ With the thrill and dread of a world falling apart, we unconsciously withdraw our desires back to the self in which case, we become a narcissist. ${ }^{79}$ Frosh argues:

... in a society in which everyone's selfhood is undermined by the rapidity of cultural, economic and technological change, by uncertainty over who controls what (accompanied by a sense that someone or something is in control of each of us), by fascination with

\footnotetext{
${ }^{74}$ Berman describes modernity by quoting from Marx and Engels' Manifesto of the Communist Party that "all that is solid melts into air." See Marshall Berman, All that is Solid Melts into Air (New York: Penguin Books, 1988), 13-21.

75 See Christopher Lasch, Preface to The Minimal Self (New York: W.W. Norton and Company, 1984).

${ }^{76}$ See Fromm, Greatness and Limitations of Freud's Thought, 42.

77 In Freud's psycho-sexual development, the infant is described as primarily a narcissist. He cannot distinguish yet the difference between the "I" and the "not-I". He and the objects around are considered to be one. Hence, whatever he desires, it must be fulfilled. There is a feeling of grandiosity and omnipotence rooted in the symbiotic absorption in the mother as far as the infant is concerned. See Frosh, Identity Crisis: Modernity, Psychoanalysis, and the Self, 104. However, in the process of individuation, the child gradually experiences hunger, frustrations, and helplessness which are so different from his former state of grandiosity and omnipotence. Soon the child now realizes that satisfaction of his desires lies outside of the "I" i.e., there exists a "not-I" which is the source of one's satisfaction or frustration. Cf. Lasch, The Minimal Self, 166167. However, a 'stuck' self, still fixated on archaic grandiose self-configurations and narcissistically-cathected objects, is at the source of narcissistic pathology. See Frosh, Identity Crisis: Modernity, Psychoanalysis, and the Self, 107.

${ }^{78}$ Since everything ruptures to constant changes because of the massive concentration of the capital, Frosh argues that our culture brings about a spinning of the self which is actually in the form of violence with which each of us has to struggle in order to survive. See Frosh, Identity Crisis: Modernity, Psychoanalysis, and the Self, 77.

${ }^{79}$ See Erich Fromm, The Heart of Man: Its Genius for Good and Evil (New York: Harper and Row, 1964), 31.
}

(c) 2017 lan Raymond B. Pacquing

http://www.kritike.org/journal/issue 20/pacquing june2017.pdf

ISSN 1908-7330 


\section{NEOLIBERALISM AND OUR PRECARIOUS CULTURE}

fantasies centred on interchangeable images, and by a severing of roots and traditions in the context of an increasing sameness of culture ... social uncertainty produces individual disease; personal emptiness leaves one open to the fragmenting and demeaning impact of collective regression. ${ }^{80}$

Regression into a "child-like" manner aspires for a security and this aspiration is the point of what Fromm calls transference. The presence of neoliberal paradigm in our midst leaves us with nothing but a strategy for survival. Within the market economy, our subsistence is coursed through either sublimation or reaction formation. ${ }^{81}$ As neoliberalism feeds our narcissistic desires, we sublimate our libidinal drives back to the anal stage where love for possessions is of great importance. The market intensifies our delight for having possessions through "images" and "appearances," which find expressions in the unlimited influx of goods and services. We alter our perception not just of the self but also the world outside the self. Lasch argues that we "create a world of mirrors, insubstantial images, illusions increasingly indistinguishable from reality. The mirror effect makes the subject an object; at the same time, it makes the world of objects an extension or projection of the self." 82 The "I" reconstructs itself so that reality would all depend on "I am me, in that I am me, and you are you, in that you are you." 83 In this case, through these 'images', the "I" creates its own lifestyle and sphere of experiences. The individual tends to embrace only those who fall on the same "I" category. In other words, we transfer our security, productivity, freedom, and will unto this superficial neoliberal construct. ${ }^{84}$ We have created

80 See Frosh, Identity Crisis: Modernity, Psychoanalysis, and the Self, 103.

81 See Fromm, "Psychoanalytic Characterology and Its Relevance for Social Psychology," 164-166. The sublimation of the anal eroticism is a continuation of the original love for feces since this is the first possession of the child. In adult life, this finds "expression in love for possessions ... People enjoy a possession only if no one else has anything like it. They are inclined to regard everything in life as property and to protect everything that is "private" from outside invasion. This attitude does not apply to money and possessions only; it also applies to human beings, feelings, memories, and experiences. The strength of the underlying libidinous tendencies, which associate property with the private sphere, can readily be gauged by their rage over any invasion into their private life, their "freedom." See Ibid., 170-173.

${ }^{82}$ Lasch, The Minimal Self, 30.

${ }^{83}$ See Rainer Funk, "Living by the manual: Ego-oriented social character- pathogenic effects of globalization" in International Forum of Psychoanalysis, 19 (2010): 86.

${ }^{84}$ For Fromm, in the individuation process, the helplessness and powerlessness of the child is a symptom of a need, i.e. a need for a security in the person of his parents. However, it is often neglected, according to him, that it is not only the child who is in need of security. The parents too feel helpless and powerless in the midst of the social forces surrounding them. Fromm says, "What is often overlooked, however, is the fact that the adult is helpless too. In

(c) 2017 lan Raymond B. Pacquing

http://www.kritike.org/journal/issue 20/pacquing_june2017.pdf

ISSN 1908-7330

(cc) BY-NC-ND 
for ourselves illusions which introject unto our lives. The very texture of human lifeworld is schematized in accordance with nuggets of enjoyment in the form of superficial images and appearance. ${ }^{85}$ Hence, reality is made into objecthood, which includes the self. ${ }^{86}$ Never has been in the history of humanity that our age is characterized as the unlimited enjoyment of freedom in the sense that with the help and use of computer technology, unlimited production and unrestricted happiness turn into the nucleus of modern life. ${ }^{87}$ Nevertheless, says Fromm, all of these only obscure real issues that beset life, for they provide only temporary relief from our helplessness, boredom, and anxiety due to the colossal effect of modern capitalism. ${ }^{88}$ Secondly, with the onslaught of large scale companies and gigantic organizations, modern capitalism atomizes human beings so that recourse is to defend the ego through the phenomenon of transference. In this sense, we shut off from our horizons and begin to gaze at the horizon of the other. There is no reality within, any identity to hold on, but our reality is grounded and depends upon higher entities like institutions or the state. ${ }^{89}$ Fromm says that we "become a part of a larger unit, a pendant, a particle, at least a small one, of this 'great' person, this 'great' institution, or this 'great' idea." 90 Survival for us is to become a part, if not in toto, of great dominance. Just to feed those narcissistic desires within, we become subalterns who cannot express our own, and whenever we want to, we just repeat the ideological narratives of authority. ${ }^{91}$ This is the reason why, in Fromm's thinking, our lives always revolve around the psychic apparatus of domination and control, without which, we feel a meaningless existence. We need externalities to confirm who we are. We need the power from the "other" - whether it is a unit, a pendant, an article, or great institutions or people-just to allow our own individuality to grow and

many situations which the child could not manage, the adult knows what to do but is, in the last analysis, also extremely helpless." See Fromm, Greatness and Limitation of Freud's Thought, 42.

${ }^{85}$ See Dean, Democracy and Other Neoliberal Fantasies, 50.

86 Cf. See Stanley Aronowitz and Henry Giroux, Education Under Siege (London: Routledge and Keagan Paul, 1986), 48-49.

${ }^{87}$ Cf. Fromm, Revolution of Hope, 38-45.

${ }^{88}$ See Fromm, On Being Human, 53.

${ }^{89}$ See Erich Fromm, "Being Centrally related to the Patient" in The Clinical Erich Fromm: Personal Accounts and Papers on Therapeutic Technique, ed. by Rainer Funk (New York: Radopi, 2009), 12.

${ }^{90}$ See Erich Fromm, "Authoritarian Personality," trans. by Florian Nadge, in Deutsche Universitätszeitung, 12:9 (1957): 3-4.

${ }^{91}$ See San Juan, From Globalization to National Liberation, 2. Fromm also comments that the bureaucratic capitalist machine has dislodge human rationality since every individual is under the illusion of having opinions when in fact he just repeats what this gigantic bureaucracy tells him. See also Erich Fromm, "The Automaton Citizen and Human Rights," in Fromm Forum, 12 (2008): 11-16.

(c) 2017 lan Raymond B. Pacquing

http://www.kritike.org/journal/issue 20/pacquing june2017.pdf

ISSN 1908-7330 


\section{NEOLIBERALISM AND OUR PRECARIOUS CULTURE}

develop. All of these just nourish the psychic regression caused by the precariousness of our culture.

\section{Conclusion}

The cause of neoliberal expediency is something not to be taken for granted. Although the real intention in alleviating human life and raising the dignity of man is a much-celebrated milestone on human history, we cannot disregard the fact that the negative impact of the market economy on our lives sent us into a vast vacuum where the thrilling, trampling, spinning, and elbowing become the value in order to survive. The shattering of our traditional values as Filipinos deepens the void, which in turn propels us into regression. There is nothing solid when neoliberal propaganda subsumes every facet of our lifeworld, i.e., when our consciousness is transposed into instrumentalities - "with how we are doing things; we are no longer concerned with why we are doing things. We build machines that act like men and we want to produce men who act like machines." 92 The routinary events that envelop life and the rationalizations that arise therein separate the individual from his real self, i.e., the self which is productive and creative, and the self that wants to transcend to find its unity and purpose..$^{93}$

Put simply, neoliberalism has "paralyzed human rationality to the point where [our] pride in a common humanity had subsided." 94 There is no longer a ground, a security, or an orientation in which every individual person can establish his identity. The core of one's humanity collapses so that human life now becomes a point of no boundaries. The characterology brought about by modernity silenced the unconscious expression of man's deepest expression, i.e., his humanity. As a consequence, we lose concern over things that might be equally or more important for the survival of our society - tradition..$^{95}$ To end this paper, I want to emphasize that becoming to be, i.e., becoming more man, "is" more, has more access to being and "be" more fully human in all dimensions of his existence, in everything that characterizes his humanity - all of these are done through our own cherished values and traditions. ${ }^{96}$ It is within these values and traditions that we acquire

\footnotetext{
92 Fromm, "Freedom in the Work Situation", 3.

${ }^{93}$ Cf. Philip J. Vergragt, "How Technology Could Contribute to a Sustainable World" in GTI Paper Series, 8 (2006), 4.

${ }^{94}$ Lawrence Friedman, The Lives of Erich Fromm: Love's Prophet (New York: Columbia University Press, 2013), 228.

95 Cf. Charles Taylor, The Ethics of Authenticity (Massachusetts: Harvard University Press, 1991), 14.

${ }^{96}$ See De Torre, Work, Culture, Liberation, 17-18.

(c) 2017 lan Raymond B. Pacquing

http://www.kritike.org/journal/issue 20/pacquing june2017.pdf

ISSN 1908-7330
}

(c) BY-NC-ND 
consciousness on issues, conviction on matters of the intellect, and fidelity in emotional matters. ${ }^{97}$

Department of Philosophy, University of Santo Tomas, Philippines

\section{References}

Anshen, Ruth Nanda, "World Perspectives - What This Series Means," in Erich Fromm, To Have or To Be (London: Continuum, 2008).

Aronowitz, Stanley and Henry Giroux, Education Under Siege (London: Routledge and Keagan Paul, 1986).

Bello, Walden, "Neoliberalism as Hegemonic Ideology in the Philippines: Rise, Apogee, and Crisis," in Focus on the Global South, $<$ http://focusweb.org/node/1534>.

"Neoliberalism as Hegemonic Ideology in the Philippines: Rise, Apogee, and Crisis" (Plenary Paper presented at the National Conference of the Philippine Sociological Society, Philippine Social Science Center (PSSC) Building, Quezon City, Metro Manila, 16 October 2009.

Berman, Marshall, All that is Solid Melts into Air (New York: Penguin Books, 1988).

Chomsky, Noam, Profit Over the People: Neoliberalism and the Global Order (New York: Seven Stories Press, 1999).

Clarke, Simon, "The Neoliberal Theory of Society," in Neoliberalism: A Critical Reader, ed. by Alfredo-Saad Filho and Deborah Johnston (London: Pluto Press, 2005).

Cook, Deborah, Adorno, Habermas, and the Search for a Rational Society (New York: Routledge, 2004).

De Torre, Joseph M., Identity Crisis: Modernity, Psychoanalysis, and the Self, (New York: Palgrave McMillan).

Dean, Jodi, Democracy and Other Neoliberal Fantasies (U.S.: Duke University Press, 2009).

Dunn, Robert, Identity Crises: Social Critique of Postmodernity (London, University of Minnesota Press, 1998).

Friedman, Lawrence, The Lives of Erich Fromm: Love's Prophet (New York: Columbia University Press, 2013).

Fromm, Erich, "Authoritarian Personality," trans. by Florian Nadge, in Deutsche Universitätszeitung, 12:9 (1957).

${ }_{97}$ See Fromm, “The Automaton Citizen and Human Rights."

(C) 2017 lan Raymond B. Pacquing http://www.kritike.org/journal/issue 20/pacquing june2017.pdf ISSN 1908-7330 


\section{NEOLIBERALISM AND OUR PRECARIOUS CULTURE}

"Being Centrally related to the Patient" in The Clinical Erich

Fromm: Personal Accounts and Papers on Therapeutic Technique, ed. by Rainer Funk (New York: Radopi, 2009), 12. Beyond the Chains of Illusion (New York: Continuum, 1962). "Freedom in the Work Situation," in Arbeit - Entfremdung Charakter, vol. 3 of The Yearbook of the International Erich Fromm Society (Münster: LIT Verlag, 1994). Greatness and Limitation of Freud's Thought (New York: Harper and Row, 1979). Man for Himself (New York: Holt and Company, 1947).

"Man's Impulse Structure and Its Relation to Culture" in Beyond Freud: From Individual to Social Psychology, ed. by Rainer Funk (New York: American Mental Health Foundation, 2010).

On Being Human, ed. by Rainer Funk (New York: Continuum, 1999).

"Psychoanalytic Characterology and Its Relevance for Social Psychology," in The Crisis of Psychoanalysis (New York: Henry Holt and Company, 1970).

"The Automaton Citizen and Human Rights," in Fromm Forum, 12 (2008).

The Heart of Man: Its Genius for Good and Evil (New York: Harper and Row, 1964).

The Revolution of Hope (New York: Rinehart and Holt, 1970).

The Sane Society (Canada: Holt, Rinehart, and Winston, 1955).

Frosh, Stephen, Identity Crisis: Modernity, Psychoanalysis, and the Self, (New York: Palgrave McMillan, 1991).

Fukuyma, Francis, The End of History and the Last Man (New York: The Free Press, 1992).

Funk, Rainer, Erich Fromm: The Courage to be Human (New York: Continuum, 1982).

"Living by the manual: Ego-oriented social characterpathogenic effects of globalization" in International Forum of Psychoanalysis, 19 (2010).

Giddens, Anthony, Capitalism and Modern Social Theory (New York: Cambridge University Press, 1991).

Giroux, Henry A., "Neoliberalism, Youth, and the Leasing of Higher Education," in Global Neoliberalism and Education and its Consequences (New York: Routledge, 2009), 30.

Zombie Politics and Culture in the Age of Casino Capitalism (New York: Peter Lang Publishing Co., 2011). 
Golding, Robert, "Freud, Psychoanalysis, and Sociology: Some Observations on the Sociological Analysis of the Individual," in The British Journal of Sociology, 33:4 (1982).

Hardt, Michael and Antonio Negri, Empire (London: Harvard University Press, 2000).

Harvey, David, Brief History of Neoliberalism (New York: Oxford University Press, 2005).

Hayek, F.A., The Constitution of Liberty (Chicago: University of Chicago Press, 1978).

Honneth, Axel, Reification: A New Look at an Old Idea, ed. by Martin Jay (New York: Oxford University Press, 2008).

Jocano, F. Landa, Filipino Value System (Quezon City: Research House, 1997). Issues and Challenges in Filipino Value Formation (Quezon City: Punlad Research House, 1992).

Kristol, Irving, "A Capitalist Conception of Justice," in Business Ethics, 3rd ed., ed. by W. Michael Hoffman and Robert E. Frederick (New York: McGraw Hills, Inc., 1995).

Kumar, Ravi and Dave Hill, "Introduction: Neoliberal Capitalism and Education," Global Neoliberalism and Education and its Consequences, ed. by Ravi Kumar and Dave Hill (New York: Routledge, 2009).

Lakshmanna, C., Democratic Planning: Problems and Process (Calcutta: Minerva Associates Publications, 1975).

Lasch, Christopher, The Culture of Narcissism (New York: W.W. Norton and Company, 1979). The Minimal Self (New York: W.W. Norton and Company, 1984).

Leys, Collin, "The Rise and Fall of Development Theory," in The Anthropology of Development and Globalization, ed. by Marc Edelman and Angelique Haugerud (USA: Blackwell Publishing, 2005).

Lukacs, Georg, "History and Class Consciousness 1920" in History and Class Consciousness, ed. by Andy Blunden, trans. by Rodney Livingstone (Meril Press, 1967), 12.

Mayo, Peter, "'In and Against the State': Gramsci, War of Position, and Adult Education," in Journal for Critical Education Policy Studies, 3:2 (2005).

Miller, Toby, Cultural Citizenship (Philadelphia: Temple University Press, 2007).

von Mises, Ludwig, Preface to Liberalism, trans. by Ralph Raico (California: Cobden Press, 1985).

Ozzane, Henry, "Social Character as Sociological Concept" in American Sociological Review, 8:5 (1943).

Panfilova, Tatiana, "Identity as a Problem of Today," in Fromm Forum, 14 (2010). 


\section{NEOLIBERALISM AND OUR PRECARIOUS CULTURE}

Peet, Richard, Unholy Trinity (Philippines: IBON Books, 2004).

Perelman, Michael, The Invention of Capitalism, (London: Duke University Press, 2000).

Pines, Christopher, Ideology and False Consciousness (New York: State University of New York Press, 1993).

Plehwe, Dieter and Tomm Mills, "Defending Capitalism: The Rise of the Neoliberal Thought Collective (Part 1)," in New Left Project (12 March 2012), $<$ http://www.newleftproject.org/index.php/site/article comments/d efending capitalism the rise of the neoliberal thought collective part $1>$.

Sams, Aaron Caleb, "Horkheimer and the Critique of Instrumental Reason," in Academia (2014), $<$ https://www.academia.edu/4104495/Horkheimer and the Critiqu e of Instrumental Reason>.

San Juan, E., From Globalization to National Liberation: Essays of Three Decades (Manila: UP Press, 2008). Only by Struggle (Quezon City: Giraffe Books, 2002).

Sirkar, Oishik and Dipika Jain, "Neoliberal Modernity and the Ambiguity of its Discontents: Post/Anti-colonial Disruptions of Queer Imperialism," in Jindal Global Law Review, 4:2 (2013).

Taylor, Charles, The Ethics of Authenticity (Massachusetts: Harvard University Press, 1991).

Vergragt, Philip J., "How Technology Could Contribute to a Sustainable World" in GTI Paper Series, 8 (2006).

Weiss, Frederick, "Self-Alienation, Psychoanalysis and the Wholeness of Man," in Fortschritte der Psychoanalyse. Internationales Jahrbuch zur Weiterentwicklung der Psychoanalyse, ed. by A. Heigl-Evers, vol. 1 (Göttingen: Verlag für Psychologie - Dr. C. J. Hofgrefe, 1964).

Wiggerhaus, Rolf, The Frankfurt School: Its History, Theories, and Political Significance, trans. by Michael Robertson (Cambridge: MIT Press, 1995).

Wilde, Lawrence, Erich Fromm and the Quest for Solidarity (New York: Palgrave McMillan, 2005).

Wilson, Japhy, "The Shock of the Real: The Neoliberal Neurosis in the Life and Times of Jeffrey Sachs" in Antipode, 46:1 (2014).

Žižek, Slavoj, Living in the End Times (London: Verso, 2010). 